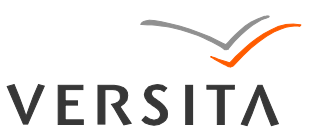

GEOCHRONOMETRIA 41(1) 2014: 30-35

DOI 10.2478/s13386-013-0144-3

Available online at

www.springerlink.com

\title{
THERMOLUMINESCENCE AGE OF QUARTZ XENOCRYSTS IN BASALTIC LAVA FROM ONINOMI MONOGENETIC VOLCANO, NORTHERN KYUSHU, JAPAN
}

\author{
YORINAO SHITAOKA ${ }^{1}$, MASAYA MIYOSHI ${ }^{2}$, JUNJI YAMAMOTO ${ }^{3}$, TOMOYUKI SHIBATA ${ }^{1}$, \\ TSUNETO NAGATOMO ${ }^{4}$ and KEIJI TAKEMURA ${ }^{1}$ \\ ${ }^{1}$ Institute for Geothermal Sciences, Kyoto University, 3088-176, Noguchibaru, Beppu, 874-0903, Japan \\ ${ }^{2}$ Faculty of Education and Regional studies, University of Fukui, 3-9-1 Bunkyo, Fukui, 910-8507, Japan \\ ${ }^{3}$ The Hokkaido University Museum, Hokkaido University, 10-8 kita-ku, Sapporo, 060-0810, Japan \\ ${ }^{4}$ Faculty of Education, Nara University of Education, Takabatake, Nara, 630-8528, Japan
}

Received 7 September 2012

Accepted 23 October 2013

\begin{abstract}
We determined the eruption age of basaltic rocks by application of thermoluminescence (TL) method, which is often used for TL dating, to quartz. Mafic magma only rarely includes quartz because of their mutual disequilibration. The basaltic lavas reported herein include quartz as xenocrysts, as corroborated by their rounded or anhedral shape.

The basaltic lava used for this study is from the Oninomi monogenetic volcano in northern Kyushu, Japan. The volcano eruption was estimated as occurring 7.3-29 ka because the lava exists between two widespread tephras: Aira-Tanzawa ash (26-29 ka) and Kikai-Akahoya ash (7.3 ka). We succeeded in collecting $c a .200 \mathrm{mg}$ of quartz by decomposition of $30 \mathrm{~kg}$ of the lava samples. TL measurements for the lava indicate the eruption age as $15.8 \pm 2.5 \mathrm{ka}$, which is fairly consistent with the stratigraphical estimation. Although the TL method has played a considerable part in constraining the timescale of Quaternary events, its application has been limited to silicic samples. The present result demonstrates the availability of quartz for dating even of mafic rock.
\end{abstract}

Keywords: Oninomi monogenetic volcano, basaltic rocks, thermoluminescence dating, quartz xenocrysts, eruption age.

\section{INTRODUCTION}

Quaternary volcanism has had a great impact on recent geographical evolution and human history. A method for precise age determination of young volcanic rocks deserves to be established. The eruption age of volcanic rocks has been determined in many cases using $\mathrm{K}-\mathrm{Ar}$ or $\mathrm{Ar}-\mathrm{Ar}$ dating, or by other means. It is nevertheless difficult to apply them to young Quaternary basaltic samples

Corresponding author: Y. Shitaoka

e-mail: shitaoka@bep.vgs.kyoto-u.ac.jp because of their low $\mathrm{K}$ contents and the possible occurrence of excess Ar. Indirect age determination using radiocarbon $\left({ }^{14} \mathrm{C}\right)$ method has served as the only method to estimate the eruption age of young basalts. Some difficulties arise in determining an eruption age via the ${ }^{14} \mathrm{C}$ method, such as possible effects of bioturbation, absorption of volcanic $\mathrm{CO}_{2}$, and difficulty in recovering adequate or sufficient carbonic matter. Alternatively the TL age dating method has been applied to quartz-rich young silicic samples (e.g., Gillot et al., 1978; Guerin and Valladas, 1980; Ichikawa et al., 1982; Kanemaki et al., 1991; 
Miallier et al., 1994). It has not been applied, however, to basaltic samples because the mafic magma usually contains no quartz. Although some pioneering reports have described TL and infra-red stimulated luminescence (IRSL) ages of feldspar in basaltic rocks (e.g., May, 1977; Tsukamoto et al., 2011), the former was controversial because of the anomalous fading of luminescence signals (Wintle, 1973). Recently, Takashima et al. (2002; 2004) applied the TL method to secondarily formed quartz crystals in altered mafic rocks. Although they demonstrated TL age determination of basaltic rocks, they ascertained not the eruption age but the hydrothermal alteration age of the basalts.

Mafic magma is disequilibrated with quartz, which makes it more difficult to discern the TL age of basaltic rock. Among our observations, however, some basaltic samples include quartz crystals with a resorption rim, which should be regarded as xenocrysts. The TL ages of such quartz xenocrysts are probably reset immediately after interaction with high-temperature basaltic magma because they easily lose luminescence signals by annealing. Therefore, the quartz xenocrysts in mafic samples are expected to be adequate for TL dating.

To assess the availability of the quartz xenocrysts as a probe for TL dating, the TL age of the quartz should be evaluated by comparison with other dating methods. Most earlier research efforts were made on TL dating using quartz extracted from heated siltstone xenolith (e.g., Chen et al., 2001), phreatic explosion (e.g., Miallier et al., 2004; Preusser et al., 2011; Rufer et al., 2012), pumice (e.g., Shitaoka et al., 2009; Miallier et al., 1994) and baked sediments by a lava flow (e.g., Pilleyre et al., 1992; Bonde et al., 2001). However, very few attempts have been made at TL dating using crustal quartz xenocrysts that have survived in host basaltic magma. Mafic lavas in the Oninomi monogenetic volcano in northern Kyushu, Japan (Fig. 1) include a tiny amount of quartz xenocrysts (Ohta et al., 1992). Although no report in the literature has described the exact age of the Oninomi volcanism, it has been estimated indirectly in tephrochronological studies. Constraints on age are extremely effective in evaluating TL age of the quartz xenocrysts. This report describes the eruption age of the Oninomi basaltic lava estimated by TL dating of the quartz xenocrysts, and presents discussion of the availability of quartz xenocrysts for investigating Quaternary basaltic activities.

\section{GEOLOGICAL SETTING}

The subduction zone in the southwestern Japan arc can be characterized by active subduction of the young Philippine Sea plate. The Oninomi monogenetic volcano is located near the intersection of the northern volcanic front of the Kyushu (Fig. 2), southwestern Japan arc with the Beppu graben system (Fig. 2). Quaternary volcanism

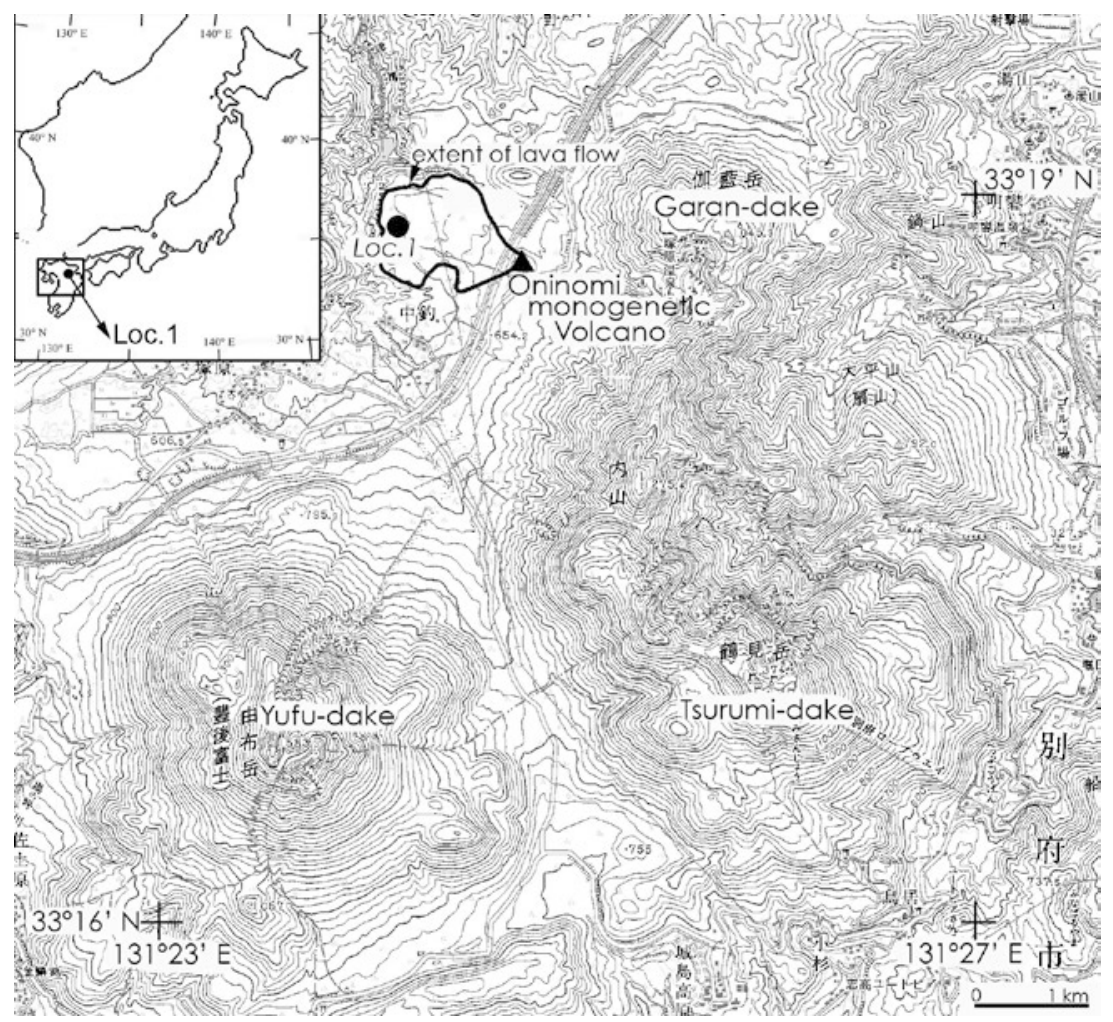

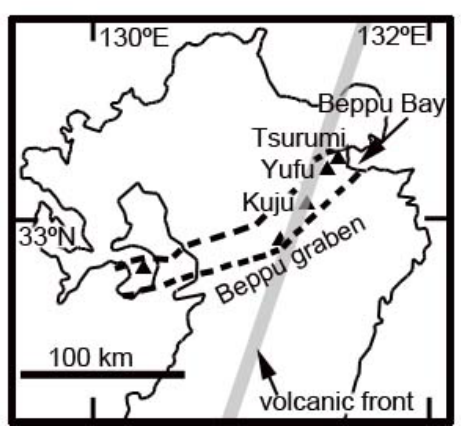

Fig. 2. Schematic map of northern Kyushu. Some volcanoes, the volcanic front, and the Beppu graben are shown.

Fig. 1. Location map for points of importance in this study. Loc.1 is the sampling point of a lava flow from Oninomi volcano. Area covered by the rectangle in inset is presented in Fig. 2. 
in the Beppu graben is composed mainly of silicic lava flow and the formation of a lava dome complex in Yufudake, Tsurumi-dake, and Kuju active volcanoes. The basaltic activity of Oninomi monogenetic volcano is quite rare in the graben system. Itoh et al. (1998) asserted that the Oninomi basaltic volcanisms occurred at a corner of an active rhomboidal basin in Beppu Bay (Fig. 2). The Oninomi eruption formed a scoria cone near Tsurumidake, and effused two lava flow units with no interval (Ohta et al., 1992). Ohta et al. (1992) and Kita et al. (2001) reported that the Oninomi basaltic lavas are classifiable as within-plate-type basalt based on their trace element compositions. Moreover, Itoh et al. (1998) and Yamamoto et al. (2009) showed that the strong local extension by a large releasing bend of the Median Tectonic Line (MTL) caused a rupture of the continental crust and subsequent non-arc type magma activity.

Ohta et al. (1992) reported that the Oninomi lava flows exist between two widely spread tephra horizons, which are Aira-Tanzawa ash (AT; $c a .26-29$ ka by ${ }^{14} \mathrm{C}$ method: Machida and Arai, 2003) and Kikai-Akahoya (K-Ah; ca. 7.3 ka by ${ }^{14} \mathrm{C}$ method: Machida and Arai, 2003). In addition, Fujisawa et al. (2002) estimated the age of Oninomi lava as 10.5-29 ka indirectly based on the ${ }^{14} \mathrm{C}$ ages for overlying tephra layers of Tsurumi volcano. Therefore, the above constraints on the age of Oninomi volcanism are useful to evaluate the TL age of the quartz xenocrysts.

\section{PETROGRAPHY}

The modal composition of the Oninomi lava samples was analyzed using an automatic point counter. The Oninomi lava samples included $13-15$ vol.\% phenocryst content as olivine (4-5 vol.\%, $<1.5 \mathrm{~mm}$ ), clinopyroxene $(1-4$ vol. $\%,<1 \mathrm{~mm})$, plagioclase $(5-6$ vol. $\%,<2 \mathrm{~mm})$, and opaque minerals $(<0.8 \mathrm{~mm})$. The olivine was euhedral or subhedral, sometimes showing a skeletal texture. Clinopyroxene was euhedral or subhedral. Clear euhedral plagioclase coexists with dusty anhedral plagioclase. A dusty zone was observed along the resorption rim of anhedral plagioclase. The Oninomi lava samples also contained minor $(<1 \mathrm{vol} . \%)$ xenocrysts of hornblende $(<3 \mathrm{~mm})$ and quartz $(<1 \mathrm{~mm})$. Hornblende, observed as pseudomorph, was completely opacitized. The quartz xenocrysts were surrounded by a reaction rim of pyroxene (Fig. 3). Ohta et al. (1992) reported that these disequilibrated quartz crystals are derived from silicic basement rock based on the description of crustal xenoliths in Oninomi samples. The groundmass showed an intergranular or intersertal texture with microlites of pyroxene, plagioclase, and opaque minerals.

\section{SAMPLE PREPARATION AND ANALYSIS}

We used approximately $30 \mathrm{~kg}$ of rock samples for this study, which were collected from a lava flow of Oninomi volcano (Fig. 1). The surface layer of the rock samples, which had been exposed to sunlight, thereby reducing their luminescence, was removed using a diamond cutter. Then the samples were sieved into a fraction of 250 $50 \mu \mathrm{m}$ using a crusher and standard sieves. The sieved samples were treated initially with $20 \% \mathrm{HCl}$ for $90 \mathrm{~min}$. Feldspar and the other minerals except quartz were separated by etching with $20 \% \mathrm{HF}$ for $90 \mathrm{~min}$. The etched fraction (natural sample) was sieved into $150-75 \mu \mathrm{m}$ grain size range to remove smaller grains and partially etched feldspars. We made a speculum, IRSL measurement after etching with $20 \% \mathrm{HF}$ and sieving. If feldspar remained, samples were treated with $46 \% \mathrm{HF}$; then IRSL was measured. The acid treatment was repeated to achieve complete elimination of feldspar. After the treatment, we obtained no signal of feldspar by XRD analysis. Approximately $200 \mathrm{mg}$ quartz was obtained using this preparation.

The TL measurements were performed using the original TL/OSL reader NRL-99-OSTL (Nagatomo et al., 2007) at Nara University of Education (NUE). Samples were heated at a rate of $5^{\circ} \mathrm{C} / \mathrm{s}$ from $100^{\circ} \mathrm{C}$ to $400^{\circ} \mathrm{C}$ in a nitrogen atmosphere. The TL signal of $570-700 \mathrm{~nm}$ from a sample was guided to a photomultiplier tube (H7360 01; Hamamatsu Photonics K.K., Japan) through two condensing lenses and filters (OG570; Schott AG and HA50; Hoya Corp.). Additive doses were administered using a ${ }^{60} \mathrm{Co}$ gamma-ray source at NUE.

A standard multiple aliquot additive dose (MAAD) protocol (Aitken, 1985) was applied to the treated sample. In the MAAD protocol, TL is measured for both the natural sample and additive dose sample (artificially irradiated samples). The samples were divided into 20 fractions. Then some fractions were exposed to 25, 50, and 75 Gy with the ${ }^{60} \mathrm{Co}$ gamma ray at a dose rate of $c a$. $0.2 \mathrm{~Gy} / \mathrm{min}$. The equivalent dose of the sample can be

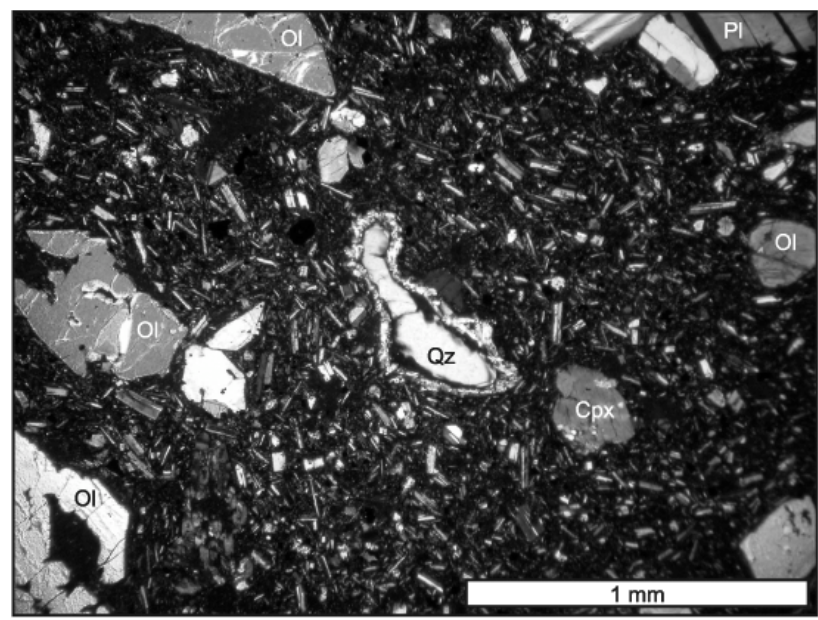

Fig. 3. Photomicrograph of a lava sample from the Oninomi monogenetic volcano. Abbreviations: Ol: olivine; Cpx: clinopyroxene; Pl: plagioclase; Qz: quartz. 
estimated by fitting the data assuming linear dose dependence. Consequently, for correcting the nonlinear portion in the low-dose region, we measured TL of samples that had been annealed at $350^{\circ} \mathrm{C}$ for $60 \mathrm{~min}$.

The annual dose (dose rate) measurements were performed using a gamma-ray spectrometer. The concentrations of $\mathrm{U}, \mathrm{Th}$, and $\mathrm{K}$ in the sample were analyzed using a Ge gamma-ray detector (EGSP 8785; Eurisys Mesures) at NUE. For the annual dose estimation, host lava sample was analyzed. The annual dose was calculated using dose-rate conversion factors (Adamiec and Aitken, 1998). The quartz xenocrysts grain size was from $500-1000 \mu \mathrm{m}$. We crushed them to between $150 \mu \mathrm{m}$ and $75 \mu \mathrm{m}$ during sample preparation. The beta attenuation factors were taken by Mejdahl (1979) as the grain size $750 \mu \mathrm{m}$. Contributions of the cosmic-dose rate to the annual dose were assumed according to methods described in earlier reports by Prescott and Hutton (1994) and by Shitaoka et al. (2009).

\section{RESULTS}

Fig. 4A presents TL measurement results. The equivalent dose was estimated by extrapolation of the linear trend in diagrams of TL growth vs. dose (Fig. 4B (a)). The temperature region of $320-335^{\circ} \mathrm{C}$ was satisfied with the plateau test (Aitken, 1985). The estimation method for nonlinearity correction ( $\Delta$ in Table 1$)$ was analogous to that of the equivalent dose (Fig. 4B (b)). The palaeodose of the sample was the sum of the equivalent dose and the nonlinearity correction.
The annual dose was obtained as the sum of beta, gamma, and cosmic dose rates. The palaeodose, annual dose, and TL age are presented in Table 1 . The obtained TL age of the lava flow of the Oninomi monogenetic volcano was $15.8 \pm 2.5 \mathrm{ka}$.

The error of the palaeodose was $c a .15 .7 \%$, as shown in Table 1, which resulted from scattering of data in the glow curves of additive dose samples (Fig. 4A). It is likely to have resulted from instability of the detector, because the red-hot glow could not be completely cut by the optical filters. To reduce the uncertainty of obtained palaeodose, it will be necessary to repeat the TL measurement or to develop a TL detection system to cut the red-hot glow.

\section{DISCUSSION}

\section{Applicability of quartz xenocrysts for TL dating}

To apply quartz xenocrysts as a probe for TL dating, it is necessary that the TL signal in the quartz be removed completely at the time of eruption. The effectiveness of zeroing of the TL signal depends on some annealing conditions such as the temperature, duration, and quartz size. Reaction coronas around the quartz (Fig. 3) offer a clue to understanding of the annealing conditions. Sato (1975) proposes that reaction coronas around the quartz xenocrysts in mafic lava can be interpreted as diffusion coronas. He succeeded in reproducing the coronas by annealing of polyhedral quartz with fine powder of basalt at $1400^{\circ} \mathrm{C}$ for $7 \mathrm{hr}$. The magmatic temperature in the subduction zone settings has been estimated as 800

Table 1. Result of TL dating for Oninomi basaltic lava.

\begin{tabular}{|c|c|c|c|c|c|c|c|c|c|}
\hline $\begin{array}{l}\text { Equivalent } \\
\text { dose (Gy) }\end{array}$ & $\begin{array}{c}\Delta \\
(G y)\end{array}$ & $\begin{array}{c}\text { Paleodose } \\
\text { (Gy) }\end{array}$ & $\begin{array}{c}U \\
\text { (ppm) }\end{array}$ & $\begin{array}{c}\text { Th } \\
\text { (ppm) }\end{array}$ & $\begin{array}{c}\mathrm{K}_{2} \mathrm{O} \\
(\mathrm{wt} \%)\end{array}$ & $\begin{array}{c}\beta \text { ray } \\
\text { (mGy/a) }\end{array}$ & $\begin{array}{l}Y+\text { Cosmic } \\
\text { ray (mGy/a) }\end{array}$ & $\begin{array}{c}\text { Annual dose } \\
\text { (mGy/a) }\end{array}$ & $\begin{array}{l}\text { TL age } \\
\text { (ka) }\end{array}$ \\
\hline $13.1 \pm 2.3$ & $13.0 \pm 3.3$ & $26.1 \pm 4.1$ & $0.90 \pm 0.08$ & $5.50 \pm 0.35$ & $1.41 \pm 0.10$ & $0.86 \pm 0.06$ & $0.80 \pm 0.03$ & $1.66 \pm 0.07$ & $15.8 \pm 2.5$ \\
\hline
\end{tabular}
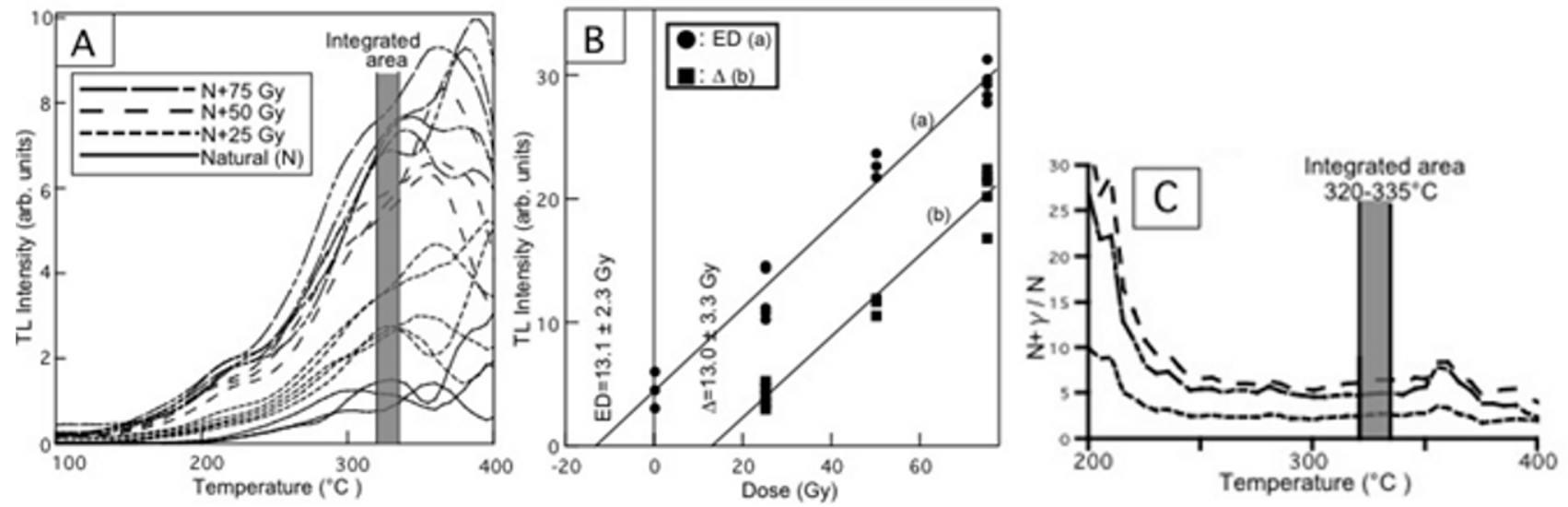

Fig. 4. TL glow curves (A), TL growth curve (B) and Plateau test (C). The plateau test was derived by N+Gamma / N. The plateau area (integrated area) is $320-335^{\circ} \mathrm{C}$. The equivalent dose $(E D)$ and nonlinearity correction $(\Delta)$ were estimated using the $T L$ growth curve. 
$1100^{\circ} \mathrm{C}$ using mineral thermometers (e.g., Tamura, 1994; Straub, 2008). Even in cases of magmatic temperature of $1100^{\circ} \mathrm{C}$, reproducing the coronas takes ten times ( $c a$. 3 days) as long, or longer, than the time reported by Sato (1975). It is a sufficient time to raise the temperature in quartz xenocrysts of millimeter scale to the surrounding magmatic temperature. Therefore zeroing of the TL signal in the quartz certainly occurred during eruption and subsequent cooling period. The annealing of the quartz xenocrysts did not occur under a specific environment. It is, therefore, safe to say that quartz xenocrysts have the potential of elucidating the eruption age of host magma even if the magma has a mafic composition. The quartz grains used for this study were derived from crustal fragments trapped by ascending magma. Some advantages of using such exotic quartz as a TL index are as follows. One is that it covers young volcanic rocks of all kinds. We often observe quartz xenocryst even in basaltic rock as in the case of this study. Therefore TL dating using quartz xenocryst does not make any distinction according to the volcanic rock type. The other is complete zeroing of TL signal. The xenocryst quartz has survived within the basaltic magma. We did not observe phenocrystic amphibole in the basalt. Crystallization temperature of amphibole for the system of alkali basalt is higher than $1000^{\circ} \mathrm{C}$ (Yoder and Tilley, 1962), indicating that the eruption temperature of Oninomi basalt exceeded $1000^{\circ} \mathrm{C}$. In addition, the existence of pyroxene reaction rim on quartz xenocrysts (Fig. 3) shows that these quartz xenocrysts were partially melted, and reacted with the host basaltic magma at high temperature. Consequently, the TL signal of the quartz was reset completely during entrainment by the basaltic magma.

Comparison of the eruption age of Oninomi lava with that of surrounding tephra was useful to evaluate the accuracy of TL dating using quartz xenocrysts. Ohta et al. (1992) showed that Oninomi lava exists between two widespread tephra layers, AT (ca. 26-29 ka) and K-Ah (ca. $7.3 \mathrm{ka}$ ) (Machida and Arai, 2003). In addition, Fujisawa et al. (2002) proposed that the age of the Oninomi lava was slightly older than $c a$. $10.5 \mathrm{cal} \mathrm{ka}$ BP based on ${ }^{14} \mathrm{C}$ data of the overlying tephra layer on surrounding volcanoes. The TL age of $15.8 \pm 2.5 \mathrm{ka}$ obtianed in this study is consistent with the tephrostratigraphical estimation and Fujisawa et al. (2002).

\section{CONCLUSIONS}

We conducted age dating for a Quaternary basaltic lava from the Oninomi monogenetic volcano by analyzing quartz xenocrysts, obtaining the TL age of $15.8 \pm 2.5 \mathrm{ka}$, which is consistent with the previously estimated tephrochronological age and with ${ }^{14} \mathrm{C}$ data $(c a .10 .5-29 \mathrm{ka})$. Our results suggest that TL dating is widely available to quartz xenocrysts even in mafic samples. Further determination of TL age of quartz xenocrysts is expected to have great potential for clarifying volcanic history in the Quaternary period.

\section{ACKNOWLEDGMENTS}

We wish to thank Drs. M. Okuno, S. Aoki, S. Hiraga, N. Hasebe, S. Nagao, and K. Yamamoto, who provided us data and many useful comments. This study was supported financially in part by Research Fellowships from the Institute for Geothermal Sciences, Kyoto University.

\section{REFERENCES}

Adamiec G and Aitken MJ, 1998. Dose-rate conversion factors: update. Ancient TL 16: 37-50.

Aitken MJ, 1985. Thermoluminescence Dating. Academic Press, London

Bonde A, Murray A and Friedrich WL, 2001. Santorini: Luminescence dating of a volcanic province using quartz? Quaternary Science Reviews 20(5-9): 789-793, DOI 10.1016/S0277-3791(00)00034-2.

Chen YG, Wu WS, Chen CH and Liu TK, 2001. A date for volcanic eruption inferred from a siltstone xenolith. Quaternary Science Reviews 20(5-9): 869-873, DOI 10.1016/S0277-3791(00)00047-0.

Fujisawa Y, Okuno M, Nakamura T and Kobayashi T, 2002. Eruptive activities of Tsurumi volcano in Japan during the past 30,000 years. The Journal of the Geological Society of Japan 108: 48-58. (in Japanese, with English abstract).

Gillot PY, Valladas G and Reyss JL, 1978. Dating of lava flow using a granitic enclave: Application to the Laschamp magnetic event PACT (Journal of the European Study Group on Physical, Chemical and Mathematical Techniques Applied to Archaeology) 2: $165-173$.

Guerin G and Valladas G, 1980. Thermoluminescence dating of volcanic plagioclases. Nature 286: 697-699, DOI 10.1038/286697a0.

Ichikawa Y, Hagihara N and Nagatomo T, 1982. Dating of pyroclastic flow deposits using the quartz inclusion method. PACT (Journal of the European Study Group on Physical, Chemical and Mathematical Techniques Applied to Archaeology) : 409-416.

Itoh Y, Takemura K and Kamata H, 1998. History of basin formation and tectonic evolution at the termination of a large transcurrent fault system: deformation mode of central Kyushu, Japan. Tectonophysics $\quad 284(1-2): \quad 135-150, \quad$ DOI $\quad 10.1016 / \mathrm{S} 0040-$ 1951(97)00167-4.

Kanemaki M, Ninagawa K, Yamamoto I, Nakagawa M, Wada T, Yamashita Y and Endo K, 1991. Red thermoluminescence of volcanic glass fractions from tephras. International Journal of Radiation Applications and Instrumentation. Part D. Nuclear Tracks and Radiation Measurements 18(1-2): 81-88, DOI 10.1016/13590189(91)90097-2.

Kita I, Yamanoto M, Asakawa Y, Nakagawa M, Taguchi S and Hasegawa $\mathrm{H}, 2001$. Contemporaneous ascent of within-plate type and island-arc type magmas in the Beppu-Shimabara graben system, Kyushu island, Japan. Journal of Volcanology and Geothermal Research 111(1-4): 99-109, DOI 10.1016/S0377-0273(01)002220 .

Machida H and Arai F, 2003. Atlas of tephra in and around Japan. University of Tokyo Press, Tokyo. (in Japanese).

May RJ, 1977. Thermoluminescence dating of Hawaiian alkalic basalts. Journal of Geophysical Research 82(20): 3023-3029, DOI 10.1029/JB082i020p03023.

Mejdahl V, 1979. Thermoluminescence dating: beta-dose attenuation in quartz grains. Archaeometry 21(1): 61-73, DOI 10.1111/j.14754754.1979.tb00241.x.

Miallier D, Fain J, Sanzelle S, Pilleyre TH, Montret M, Soumana S and Falguérest C, 1994. Attempts at dating pumice deposits around $580 \mathrm{ka}$ by use of red TL and ESR of xenolithic quartz inclusions. Radiation Measurements 23(2-3): 399-404, DOI 10.1016/13504487(94)90070-1. 
Miallier D, Condomines M, Pilleyre T, Sanzelle S and Guittet J, 2004. Concordant thermoluminescence and ${ }^{238} \mathrm{U}-{ }^{230} \mathrm{Th}$ ages for a trachytic dome (Grand Sarcoui) from the Chaîne des Puys (French Massif central). Quaternary Science Reviews 23(5-6): 709-715, DOI 10.1016/j.quascirev.2003.06.002.

Nagatomo T, Shitaoka Y and Kunikita D, 2007. IRSL Dating of the Sediments at the Neolithic Sites in the Russian Far East. Bulletin of Nara University of Education 56(2): 1-6. (in Japanese, with English abstract)

Ohta T, Hasenaka T, Ban M and Sasaki M, 1992. Characteristic Geology and Petrology of non-arc type volcanism at Oninomi monogenetic volcano, Yufu-Tsurumi graben. Bulletin of the Volcanological Society of Japan 37: 119-131. (in Japanese, with English abstract)

Pilleyre Th, Montret M, Fain J, Miallier D and Sanzelle S, 1992. Attempts at dating ancient volcanoes using the red TL of quartz. Quaternary Science Reviews 11(1-2): 13-17, DOI 10.1016/02773791(92)90036-8.

Prescott JR and Hutton JT, 1994. Cosmic ray contributions to dose rates for luminescence and ESR dating: Large depths and long-term time variations. Radiation Measurements 23(2-3): 497-500, DOI 10.1016/1350-4487(94)90086-8.

Preusser F, Rufer D and Schreurs G, 2011. Direct dating of quaternary phreatic maar eruptions by luminescence methods. Geology 39(12): 1135-1138, DOI 10.1130/G32345.1.

Rufer D, Gnos E, Mettier R, Preusser F and Schreurs G, 2012. Proposing new approaches for dating young volcanic eruptions by luminescence methods. Geochronometria 39(1): 48-56, DOI 10.2478/s13386-011-0049-y.

Sato H, 1975. Diffusion coronas around quartz xenocrysts in andesite and basalt from Tertiary volcanic region in northeastern Shikoku, Japan. Contributions to Mineralogy and Petrology 50(1): 49-64, DOI 10.1007/BF00385221.

Shitaoka Y, Nagatomo T and Obata N, 2009. Age determination of
Ontake Pm1 pumice fall deposit (On-Pm1) by thermoluminescence method. The Quaternary Research 48: 295-300. (in Japanese).

Straub SM, 2008. Uniform processes of melt differentiation in the central Izu Bonin volcanic arc (NW Pacific). Geological Society, London, $\quad$ Special Publications 304: 261-283, DOI 10.1144/SP304.13.

Takashima I, Nasution A and Muraoka H, 2002. Thermoluminescence dating of volcanic and altered rocks in the Bajawa geothermal area, central Flores Island, Indonesia. Bulletin of the Geological Survey of Japan 53: 139-142.

Takashima I, Nazari AA, Lim PS, Koseki T, Mouri Y, Nasution A and Eddy Sucipta IGB, 2004. Thermoluminescence age determination of quaternary volcanic rocks and alteration products at Tawau area, Sabah, Malaysia. Journal of the Geothermal Research Society of Japan 26(3): 273-283.

Tamura Y, 1994. Genesis of island arc magmas by mantle-derived bimodal magmatism: evidence from the Shirahama group. Japan. Journal of Petrology 35(3): 619-645, DOI 10.1093/petrology/35.3.619.

Tsukamoto S, Duller GAT, Wintle AG and Muhs D, 2011. Assessing the potential for luminescence dating of basalts. Quaternary Geochronology 6(1): 61-70, DOI 10.1016/j.quageo.2010.04.002.

Wintle AG, 1973. Anomalous Fading of Thermo-luminescence in Mineral Samples. Nature 245(5421): 143-144, DOI 10.1038/245143a0

Yamamoto J, Nishimura K, Sugimoto T, Takemura K, Takahata N and Sano Y, 2009. Diffusive fractionation of noble gases in mantle with magma channels: Origin of low $\mathrm{He} / \mathrm{Ar}$ in mantle-derived rocks. Earth and Planetary Science Letters 280(1-4): 167-174, DOI 10.1016/j.epsl.2009.01.029.

Yoder HS and Tilley CE, 1962. Origin of basalt magmas: an experimental study of natural and synthetic rock systems. Journal of Petrology 3(3): 342-532, DOI 10.1093/petrology/3.3.342. 